\title{
Jesus en sy dissipels se reaksie op geweld in die Johannesevangelie
}

\author{
Jan van der Watt en Kobus Kok \\ Departement Nuwe-Testamentiese Wetenskap \\ Universiteit van Pretoria
}

\begin{abstract}
The reaction of Jesus and his disciples to violence in the Gospel of John

This article is the second of two articles in which violence in the Gospel of John is discussed. It is argued that Jesus' disciples used techniques of vilification in the Gospel, inter alia as way of dealing with the violence they experience at the hands of their opponents. Closer investigation reveals that they use vilification against their opponents as a pragmatic device for missionary purposes.
\end{abstract}

\section{INLEIDING}

In die vorige artikel is daar op die geweld van die opponente van Jesus teen hom en sy dissipels gefokus. Die vraag is nou hoe die volgelinge van Jesus hierdie sterk geweldsaksies verwerk het. Die verhaal van Jesus is eintlik 'n geweldsverhaal teen Jesus. Hy word verwerp (Joh 1:9-11), gehaat, vervolg en uiteindelik doodgemaak. Jesus se volgelinge was in die minderheid en kon die geweld teen hulle eintlik nie met soortgelyke geweld keer nie. Die paar dissipels kon nie die kruisiging van Jesus keer nie. Kontra-geweld sou hulle einde beteken, aangesien die magsoorwig in die guns van die opponente oorweldigend was. Wat hier volg is enkele van die belangrikste wyses waarop die volgelinge van Jesus die geweld teen hulle hanteer het.

\section{REAKSIES VAN JESUS EN SY DISSIPELS OP DIE GEWELD VAN HULLE JOODSE OPPONENTE}

\subsection{Fisieke geweld van die kant van Jesus en sy dissipels?}

Van die kant van Jesus en sy dissipels is daar eweneens 'n gewelddadige aksielyn, maar met die klein verskil dat fisieke geweld geheel en al ontbreek. 
Behalwe vir die Petrusgebeure wat Malgus met sy swaard toegetakel het (Joh 18:10 - kyk Wengst 2001:204; Haenchen 1980:518) en moontlik die reiniging van die tempel waar Jesus 'n sweep gevleg en die diere uitgedryf het (Joh 2:13-17 - Morris 1995:169; Schnackenburg 1990:1.346), is daar geen sprake van enige fisieke geweld wat van die kant van die volgelinge van Jesus moet of mag kom nie. Jesus se gewelddadige optrede met sy sweep gedurende die tempelreiniging is moeilik om te beoordeel omdat daar in die verhaal geen kontra-geweld was nie. Die tempelwagte het nie ingegryp nie en die Jode het Jesus nie te lyf gegaan nie. Dit wil dus voorkom of die sweep nie teen mense gebruik is nie, maar op diere en dat die teenwoordiges moontlik die aksie eerder simbolies as ywer vir die huis van die Here verstaan het eerder as 'n aggressiewe geweldsdaad (so ook Ridderbos 1997:115-116). Vandaar dat daar nie soos gebruiklik met geweld deur die opponente van Jesus gereageer word nie. 'n Mens sou verwag dat die tempelpolisie of die owerhede in so geval gewelddadig sou reageer. Die verhaal verbind wel die gebeure met die dood van Jesus as Jesus metafories sê dat sy liggaam die tempel is wat in drie dae afgebreek en weer opgebou gaan word (vgl Joh 2:19). Die plot van hierdie kort narratief lei nie na geweld nie, maar fokus eerder op die ywer van Jesus en die gewilligheid om sy lewe af te lê (vgl Joh 10:11). ${ }^{1}$ Dit lyk nie of Jesus geweld voorstaan ter wille van God nie, in alle geval nie geweld wat op die dood uitloop nie. ${ }^{2}$

Bowendien word Petrus sterk vermaan om nie geweld te gebruik nie (Joh 18:11) en in Joh 18:36 word die afwysing van fisieke geweld deur Jesus erteologiseer as hy sê dat sy koningskap nie van hierdie wêreld is nie, want as dit was, sou sy volgelinge geveg het sodat hy nie fisiek uitgelewer sou word nie. ${ }^{3}$ Ironies genoeg het Petrus dit probeer, maar is onmiddellik deur Jesus tereggewys, juis omdat hy nie verstaan waaroor dit werklik gaan nie (Joh 18:36; Carson 1991:594-595; Barrett 1978:537; Lindars 1972:559). Ridderbos (1997:594) is korrek as hy opmerk dat die aard van Jesus se koninkryk in Johannes verstaan moet word binne die raamwerk van sy oorsprong. Jesus se koninkryk se oorsprong is van "bo" teenoor die wêreldse koninkryk van "onder" (vgl Joh 8:23, 38).

Hier moet die volgende hermeneutiese vraag ernstig oorweeg word: wat is die bepalende hier? Stel Jesus 'n absolute teologiese standpunt van geen fisieke geweld nie, of is die volgelinge van Jesus in so 'n minderheid dat enige poging tot fisieke verset hulle uitwissing sou beteken? Op fisieke vlak

\footnotetext{
${ }^{1}$ Binne die bekende selektiewe aanbieding van gegewens binne 'n narratief moet onthou word dat die outeur van 'n narratief kies waarop die klem gelê moet word - hy is aktief in plotkonstruksie betrokke.

${ }^{2}$ Kontrasteer hiermee die opponente se optrede in Johannes 16:2 met dié van Jesus.

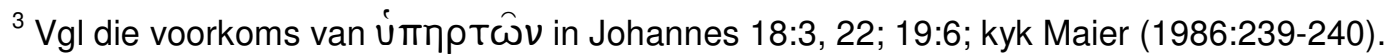


kon hulle nie eers keer dat hulle leier gevang word nie. Die paar keer wat die opponente Jesus wou vang (sien bo) was dit die ingrype van God wat dit verhoed het en nie sy dissipels nie, omdat Jesus se tyd ${ }^{4}$ nog nie daar was nie

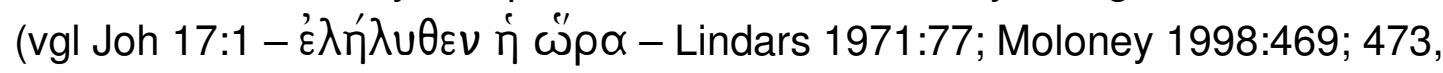
Ridderbos 1997:548). 'n Mens sou die hipotetiese vraag kon vra hoe Jesus se volgelinge op die ernstige geweld deur die dissipels van Moses sou gereageer het as hulle in die meerderheid was.

Deur die geskiedenis is hierdie vraag op verskillende maniere beantwoord. Toe die Jode in later jare in die minderheid geraak het, het fisieke vervolging juis op grond van Johannese tekste soos 8:44 gemotiveerd plaasgevind. In ander gevalle is die teks weer heeltemal pasifisties gelees. Maar voordat daar verder oor die probleem besin word, moet die aksielyne van geweld deur Jesus en sy volgelinge in die teks ontleed word.

Soos genoem is daar nie werklik aksielyne wat aktiewe fisieke geweld voorstaan nie, maar daar is tog geweld op 'n ander vlak wat eintlik parallel loop met sekere aksielyne van die opponente van Jesus. Daar is implisiete en eksplisiete geweld op sosiaal-psigologiese vlak, veral in die vorm van vilifikasie, wat die gevolg van 'n intense woordestryd was.

\subsection{Vilifikasie as geweldsmiddel in die hande van Jesus en sy volgelinge}

As minderheidsgroep blyk al werklike aanvalsmiddel tot die beskikking van Jesus en sy volgelinge retories van aard te wees, aangesien fisieke geweld na alle waarskynlikheid tot selfvernietiging sou gelei het aangesien hulle in die minderheid was. Jesus en sy dissipels ${ }^{5}$ het gevolglik hulle toevlug tot vilifikasie $^{6}$ van hulle opponente geneem.

\subsubsection{Insigloosheid, liefdeloosheid en godsdienstige bankrotskap van die dissipels van Moses}

Die dissipels van Jesus beskuldig eerstens die dissipels van Moses dat hulle voorgee om God te dien (Joh 8:54; 16:2), maar Hom in werklikheid nie ken nie (Joh 7:28; 8:19, 54-55; 15:21; 16:3; 17:25; Köstenberger 2004:267). Van Tilborg (1993:163) wys daarop dat die dissipels van Jesus die liefde wat hulle

\footnotetext{
${ }^{4}$ Vir die begrip "tyd" in Johannes, kyk Joh 2:4; 4:21, 23; 5:25, 28; 7:6, 8, 30; 8:20; 10:22; $12: 23 ; 13: 1 ; 16: 2,4,21,25,32 ; 17: 1$. Let op die voorkoms van die begrip tyd in Johannes 16 net voor Jesus uiteindelik gevange geneem word deur die Jode. Vir Johannes is God totaal in beheer van die geweld wat aan Jesus gedoen word, asook die uur waarop dit plaasvind. In 'n sekere sin val die geweld wat Jesus aangedoen word binne die raam van God se plan.

${ }^{5}$ Die veronderstelling hier is dat die Evangelie ' $n$ "tweevlak-drama" is waarin die Jesusverhaal in die verhaal van die gemeente versmelt.

${ }^{6}$ Kyk vir die beskrywing van die begrip vilifikasie in Geweld in ' $n$ evangelie van liefde in hierdie bundel.
} 
ontvang het eervol moes uitleef in die vorm van gehoorsaamheid. Die teenoorgestelde daarvan is met ander woorde vir die dissipels van Moses waar. Hulle eer nie vir Jesus nie en daarom word hulle doen en late gekenmerk deur ongehoorsaamheid en die teenoorgestelde van die eer aan die Seun en die Vader. Hulle het God nog nooit gesien of gehoor nie (Joh 8:47), want hulle is in duisternis vasgevang (Joh 9:40-41). Geestelik verkeer hulle in 'n bestaanstoestand van dood (Joh 3:19-21; 5:24) en leef in ongehoorsaamheid buite God se wil, buite die dampkring van die "geschwisterlichen Liebe" (Roloff 1993:301). Roloff (1993:301) voer die argument dat Jesus se gebod van liefde by implikasie beteken dat die gelowige nie net deel word van 'n nuwe familie nie, maar dat die gelowige ten nouste relasioneel met die Vader en sy liefde vir so 'n persoon verbind word. Dit word ook uitgedruk in 'n etiese leefstyl wat daarvan getuig. Die teendeel daarvan is ook waar: Indien iemand nie die Seun liefhet nie, het so 'n persoon ook nie toegang tot die liefde van God nie (vgl Joh 14:21, 23; 16:27). Een van die vernaamste kenmerke van hulle godsdienstige bankrotskap is dan ook

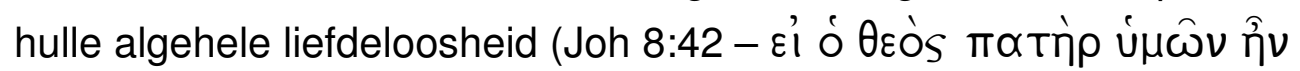

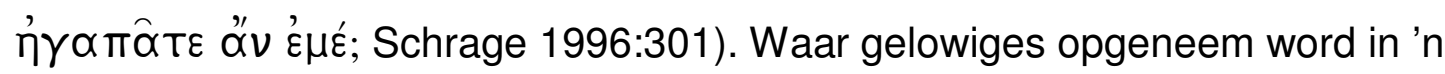
dinamiese verhoudingsbasis met die Vader en die Seun, waar intieme kennis van mekaar 'n realiteit is (Joh 14:23-28), word die dissipels van Moses uitgebeeld as dié sonder kennis en insig (vgl Joh 6:42; 7:28, 29, 49; 8:19, 32, $55 ; 10: 4,5,14,15,27 ; 14: 7,17 ; 15: 21 ; 17: 3,25)$. Van der Watt (2000:216) en Mussner (1952:172-175) stem saam dat die begrippe lewe, kennis en liefde in Johannes met mekaar verband hou soos dit duidelik blyk uit Johannes 17:3 waar lewe gedefinieer word in terme van kennis van die Vader en die Seun.

\subsubsection{Degradering van hulle herkoms en identiteit}

'n Persoon se identiteit is destyds in 'n groot mate bepaal deur sy of haar herkoms ${ }^{7}$ (wie jou pa en familie [bloedlyn]; kyk Malina \& Rohrbaugh 1998:162). Neyrey (1995:143) wys tereg daarop dat die antieke Mediterreense mense geglo het dat 'n persoon alleen geken kan word indien so 'n persoon se bloedlyn bekend is. Daar was met ander woorde 'n onlosmaaklike verband tussen bloedlyn en identiteit. Daarom is die waarskynlik bekendste en berugste uitspraak van Jesus teenoor sy opponente dat hulle kinders van die duiwel is (Joh 8:44; '̇k toû matpòs toû

\footnotetext{
${ }^{7}$ Kyk Josephus Ant. 4.8.39 §289 waar die verband tussen identiteit en herkoms eksplisiet uitgedruk word.
} 
$\delta ı \propto \beta o ́ \lambda$ ou ). ${ }^{8}$ Dit is hulle vernaamste herkoms (Neyrey 1995:143; Golden 1990:102). Hulle is inderdaad leuenaars (Joh 8:55) en moordenaars, juis omdat hulle na hulle vader, die duiwel, aard (Carson 1991:352; Brown 1966:357; Barrett 1978:348; Schnackenburg 1990:2.212; Morris 1995:393). Al dink hulle nog hulle is kinders van Abraham, of selfs van God, is hulle dit nie meer nie (Joh 8:37, 39; 41-42), want hulle het hul eie familieverbondenheid met die aartsvaders deur hulle optrede opgesê (Schnackenburg 1990:2.212). ${ }^{9}$ Immers, hulle optrede teen Jesus loën hulle identiteit as die nageslag van Abraham (Ridderbos 1997:317). Sprekend hiervan is die figuur van Judas wat Jesus verraai. In die verwysings na Judas word telkens daarna verwys dat die duiwel van hom besit geneem het. Hoewel hy saam met die dissipels van Jesus beweeg, is die duiwel in Hom (Joh 13:2, 27; 6:64, 70-71). In Johannes

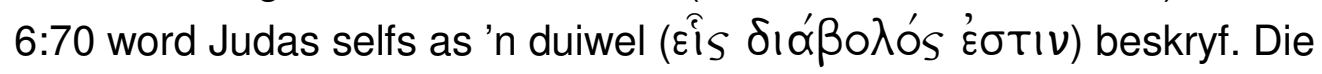
skerpheid van die uitspraak en die vilifiserende effek daarvan word goed deur Malina en Rohrbaugh (1998:162) vanuit 'n sosiaal-wetenskaplike oogpunt verduidelik:

It is difficult for Westerners to sense the insulting character of Jesus' remark. In a society in which one's honor derived from birth, insults to lineage were the most disparaging insults that could possibly be made. Jesus charges his hearers with murder and lying. He echoes precisely the ancient belief that birth determines character. In a culture that considers the devil to stand at the opposite pole from God, to call someone the offspring of the devil in an honor and shame society is a truly harsh and demeaning insult.

\subsubsection{Karaktergebreke}

In die vilifikasie van die volgelinge van Moses word hulle ook van die volgende karaktergebreke beskuldig.

\subsubsection{Arrogansie}

Die opponente se liefde vir die eer van mense en hulleself wat groter as hulle liefde vir God se eer is (Osiek \& Balch 1997:144), word telkens genoem (vgl 5:44; 12:43; Lindars 1987:223). Dit is dan juis ook in die misbruik van hulle mag dat die arrogansie van die dissipels van Moses na vore tree (Köstenberger 2004:194; Morris 1995:294; Haenchen 1980:446). Hulle eien hulle selfs die reg toe om te oordeel of Jesus Seun van God is (Joh 10:31-39).

\footnotetext{
${ }^{8}$ Philo (Spec Leg 2.243) wys daarop dat kinders streng gestraf moet word indien hulle onreg pleeg teen hulle ouers wat aan hulle die lewe geskenk het. Kinders is dus absolute lojaliteit aan ouers verskuldig gewees. Die Jode maak hulle in Johannes dus skuldig daaraan dat hulle vir God as hulle Vader en outeur van hulle lewe oneer aandoen.

${ }^{9}$ Kyk Stambauch en Balch (1986:123) vir 'n beskrywing van die Grieks-Romeinse familiebeskouing.
} 
Köstenberger (2004:194) gaan so ver as om op te merk dat die Jode so gesteld was op die eer wat hulle vir mekaar gee "... that they had no room for God's revelation. Having turned to blind spiritually, they had lost the ability to perceive God's work in their midst."

\subsubsection{Huigelary}

Die Joodse leiers word telkens van huigelary beskuldig. In Johannes 7:25-26 byvoorbeeld, wonder die mense waarom die leiers sê dat Jesus gevang moet word, maar dit nie doen nie (Barrett 1978:321; Carson 1991:317). Besef hulle nie dalk dat Jesus regtig die Messias is maar wil dit nie erken nie (Carson 1991:317)? Hulle huiwering laat dus die indruk van huigelary. Van die

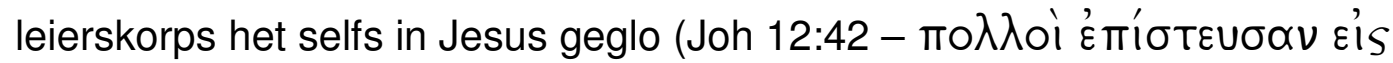
aúTóv), maar uit vrees vir die Fariseërs wou hulle dit nie bely nie (Joh 12:42).

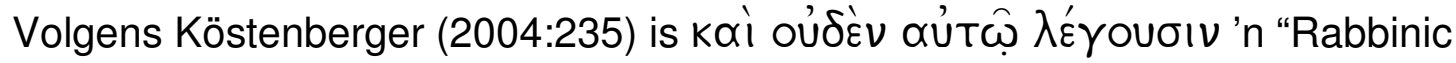
expression reflecting tacit approval" waarvolgens die indruk geskep kon word dat sommige van die Joodse leiers moontlik kon dink dat Jesus die Messias kon wees (vgl ook Brown 1966:313). Let egter op die adversatiewe $\dot{\alpha} \lambda \lambda \dot{\alpha}$ (Joh 7:25) waar die skare van mening is dat Jesus nie die Messias is nie, omdat hulle weet waar hy vandaan kom (Morris 1995:365) en dit volgens hulle nie bekend sou wees waarvandaan die Messias kom nie. Die hoogtepunt van hulle huigelary is dat hulle dink hulle dien God (Joh 16:2), maar in ' $\mathrm{n}$ oomblik van konfrontasie bely hulle dat die keiser hulle koning is (Joh 19:15; Ridderbos 1997:606). Hierdie uitspraak van die Jode word teen die agtergrond van Rigters 8:23 en 1 Samuel 8:7 belig, waar die Jode beklemtoon dat God alleen die ware Koning van Israel is. Daarmee draai hulle nie net hul rug op Jesus nie (Morris 1995:710), maar ook op die Vader en sy koninkryk (Joh 15:23; 18:36-37).

\subsubsection{Morele gebrek}

Die opponente van Jesus se morele tekortkoming word op verskeie wyses beskryf. Die opponente word deur Jesus as moordenaars en leuenaars getipeer, omdat hulle nie uit God is nie (Joh 8:44, 47). Die opmerking dat Jesus na sy eie mense gekom het, maar dat hulle hom nie aanvaar het nie (Joh 1:9-11), lê die vinger op 'n ander wond. Sosiaal het die verwerping van jou eie mense op 'n ernstige morele tekortkoming gedui (vgl Philo Spec Leg 2.243). Judas pas ook binne hierdie profiel van morele gebrek in as hy in die salwingsverhaal beskryf word as 'n dief wat die groep se geld gesteel het (Joh 12:6). 


\subsubsection{Twyfelagtig, belaglik en dom}

'n Wolk van twyfel hang reeds in Johannes 1:9-11 oor die Jode en in Johannes 2:24 oor die mense van Jerusalem (Ridderbos 1997:44; Haenchen 1984:1.117; Brown 1966:10; Moloney 1998:37). Jesus ken mense en daarom vertrou hy homself nie aan hulle toe nie. Die opponente is tekenend van swak en verkeerde oordele (Joh 7:24), veral as dit by die persoon van Jesus en die dinge van God kom (Joh 8:46-47). Die opponente van Jesus word as blindes in duisternis (Joh 9:35-41; 12:40-41) en sonder begrip geskets. In Johannes 8:53-59 word hulle onbegrip onderstreep deur' $\mathrm{n}$ reeks opmerkings wat hulle onkunde illustreer. Hulle begryp nie wie Jesus is nie (vgl Joh 6:42; 7:28, 29, 49; 8:19, 32, 55; 10:4, 5, 14, 15, 27; 14:7, 17; 15:21; 17:3, 25). Dit bly egter nie daar nie. In Johannes 9:24 vv word daar 'n tipiese Joodse strydgesprek gevoer tussen die Joodse leiers oftewel die dissipels van Moses en 'n blinde man (Culpepper 1983:93). Die blinde man se argumentasie laat die Joodse leiers telkens die onderspit delf (Hendrikson 1976:85; Carson 1991:368; Morris 1995:432; Schnackenburg 1990:2.249) tot hulle tot sosiale geweld oorgaan en die blinde man uit die sinagoge ban (Joh 9:34 - $\varepsilon^{\prime} \xi \xi^{\prime} \beta \alpha \lambda \circ \nu$; Kysar 1986:148; Thyen 2005:456-457; Wengst 2000:366; Martyn 2003). Die onwilligheid om die waarheid te aanvaar loop uiteindelik op die gesprek oor die geestelike blindheid van die Joodse leiers uit (Joh 9:39-41). Ridderbos (1997:350) merk op: "Here, of couse, reference to those that are 'blind' or can 'see' is metaphorical." Hiermee bedoel Ridderbos waarskynlik ook dat die doel van Jesus (as Lig) se koms na die wêreld nie beperk was tot die genesing van biologiese of fisieke blindheid nie, maar juis ten doel gehad het om geestelike blindheid te kom genees. Hy merk op: "For blindness is not limited to the body. One can gain physical sight and still remain blind (cf Joh 5:14)." In die volgende hoofstuk verwys Jesus metafories na die opponente as diewe en

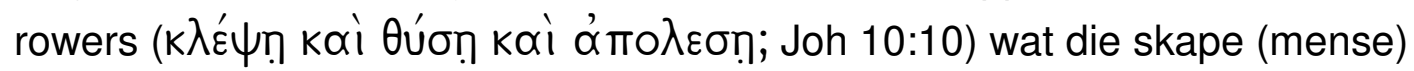
skade wil aandoen (Joh 10:1-10). Hulle moes die morele leiers wees (vgl Eseg 34), maar het nie aanvoeling of begrip vir die goddelike uniekheid van die situasie nie (Lindars 1972:361) en hulle "gesamte Lebenshaltung oder Lebensrichtung" (Bultmann 1978:261) getuig van duisternis.

\subsubsection{Onder die oordeel van God ${ }^{10}$}

Volgens Johannes 3:17-19 het God se eskatologiese oordeel ( $\left.\mathrm{p} \rho^{\prime} \mu \alpha\right)$ alreeds bloot op grond van Jesus se koms na die wêreld gerealiseer. Die koms van Jesus het as 't ware ' $n$ reuse magnetiese veld in die kosmos veroorsaak en

\footnotetext{
${ }^{10}$ Kyk Mussner (1952:98), Blank (1964:88), asook Schnackenburg (1972:427) vir 'n bespreking van God se plan om die wêreld te red en hoe die begrip van "oordeel" daarmee saamhang.
} 
mense word óf aan die positiewe óf aan die negatiewe pool daarvan geposisioneer (Hays 1996:149). Schnackenburg (1980:255) stem ook saam met Hays: "This judgment leads to a division among people, and this factor is present here as in 3:19." Tydens 'n ontmoeting met Jesus vind die oordeel by implikasie alreeds plaas en word gelowiges van ongelowiges geskei (Ridderbos 1997:351; Bultmann 1955:38).

Schnackenburg (1980:255) is dus korrek as hy opmerk: "If anyone rejects the one sent by God, their unbelief becomes a judgement on them through their own guilt (3:18b; 12:48)." Die verkeerde oordele van die dissipels van Moses bewys (kyk Joh 7, 8 en 9 vir voorbeelde) dat die opponente nie van God is nie en derhalwe onder die oordeel van God staan (Joh 3:36; 8:54-55; 12:48; Barrett 1978:350). Om mense as onder die oordeel te beskryf, is 'n bekende vorm van vilifikasie. Om hulle geestelike bankrotskap nog verder te beklemtoon, is díe een op wie hulle hulle hoop gebou het, naamlik Moses, juis die een wat hulle aankla (Joh 5:45). Köstenberger (2004:194) merk tereg op: “The Jews' hopes were set on Moses (see 9:2829); yet, ironically, it was precisely he who served as their accuser." In Jesus se tyd het die Jode Moses beskou as die middelaar van die volk en juis om hierdie rede sou Jesus se woorde skokkend voorgekom het in daardie konteks. 'n Sterk Griekse term, ó тó $\lambda \lambda$ uा (vernietig, ruïneer) word gebruik om die uiteinde van die ongelowiges te skets (Joh 3:16; 6:39; 10:28). Die "geweld" van hierdie oordeel is egter geregverdig omdat dit kom van die Koning en die Regter.

Verder beskryf Jesus sy opponente ook as diewe en rowers (Joh 10:10) wat geensins die goeie belange van die skape op die hart het nie, maar hulle eerder wil vernietig (Joh 10:1, 5, 10). Hulle motiewe word dus ernstig in twyfel getrek.

Hoewel die volgelinge van Jesus nie fisieke geweld voorgestaan het nie, blyk dit uit bogenoemde dat hulle retoriek teenoor hulle vyande vilifiserend was. Dit was dus die manier waarop Jesus en sy dissipels hulleself in ' $n$ situasie beskerm het waarin hulle self oormatige geweld ervaar het.

Natuurlik is vilifikasie daarop gemik om die opponent te benadeel en te verkleineer, maar dit was nie al doel nie. Vilifikasietaal was onder andere ook op identiteitvorming afgestem. Malina en Rohrbaugh (1998:238) wys tereg daarop dat:

Such strong oppositional language indicates the magnitude of the breach between the Johannine group and the surrounding society. This type of language abounds in the Gospel (light/dark, above/below, flesh/spirit, truth/falsehood, etc.), of course, but here it reaches a climax. Note carefully that the term love means group 
attachment, whereas the term hate means group disattachment (Love/Hate, 3:1-21). Hard boundaries are thus being drawn between those with loyalty to the group and those with none.

Die skrywer weerspieël deur die vilifikasieretoriek sy negatiewe houding teenoor die opponente en moedig die lesers aan om sy negatiewe oortuigings te deel. Op die wyse het vilifikasie dus tot identiteitsvorming asook die bou van selfvertroue bygedra. Binne die raamwerk van 'n Johannese groep sou verder gesê kon word dat vilifikasie groepstaal geword het, want dit was die wyse waarop die Johannese groep hulleself teenoor die ander kon afperk. ${ }^{11}$ Die vilifikasie van ander se karaktertrekke wys hulle staan beslis nie op morele hoë grond nie. Die morele hoë grond behoort aan die Johannese groep. ${ }^{12}$ In kort, daar hoef dus nie veronderstel te word dat die vilifiserende taal net gebruik is in die debat teenoor die opponente nie, maar dat dit ook in binnegesprekke in die Johannese groep as identiteitvormende retoriek gefunksioneer het. Met ander woorde, deur so oor jou opponente te praat, omlyn 'n mens dit waarvoor jy staan beter en voel jy dus ook meer selfversekerd en beter. Dit voorsien die groep ook van selfverdedigende argumentasie in die konfliksituasie.

\section{3 "Geweld" teen die Prins van hierdie wêreld}

'n Ander vorm van geweld word aangetref as Jesus in konflik met die duiwel geteken word. In Johannes 12:31 word genoem dat die Prins van hierdie

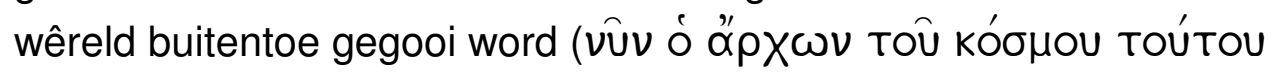

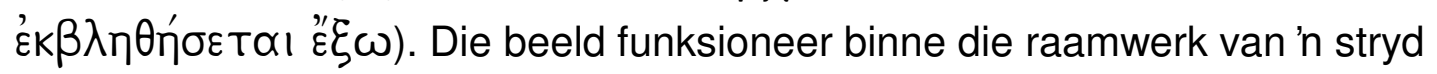
tussen twee partye: die gestuurde Messias, die koning van die Jode teenoor die Prins van hierdie wêreld. Jesus se mag oor die Prins word bo alle twyfel gestel en met die beeld uitgedruk dat die Prins eenvoudig uit sy gebied van sogenaamde heerskappy buitentoe gegooi is. Daar word dus nie veel van die stryd gemaak nie, aangesien Jesus se oorwinning bo alle twyfel staan.

\footnotetext{
${ }^{11}$ Kyk Malina en Rohrbaugh (1998:161-162; 236-240) vir 'n bespreking van binnestaanders en buitestaanders waarvolgens die wêreld in binêre terme verdeel word in diegene wat vir die groep is en dié wat teen die groep is. Vilifiserende taalgebruik funksioneer in hierdie konteks as 'n instrument om die relatiewe grense aan te dui (en te bepaal) van wie binne en wie buite die groep is (kyk ook Petersen 1993).

${ }^{12} \mathrm{Vgl} \mathrm{Johannes} \mathrm{1:17} \mathrm{waar} \mathrm{'n} \mathrm{kontras} \mathrm{geskep} \mathrm{word} \mathrm{tussen} \mathrm{Moses} \mathrm{en} \mathrm{die} \mathrm{Wet} \mathrm{aan} \mathrm{die} \mathrm{een} \mathrm{kant}$ en Christus en die waarheid aan die ander kant (let egter op die afwesigheid van die sterk kontrasterende adversiewe $\alpha \lambda \lambda \alpha$; vgl Köstenberger (2004:47-48; contra Carson 1991:132134). Net so word in Johannes 3:21 ook gesê dat die wat in die waarheid handel na die lig kom, wat by implikasie suggereer dat die wat nie by die lig is nie, nie in waarheid handel nie en by implikasie in die duisternis wandel. Die ongelowiges handel nie in die waarheid nie omdat hulle behoort aan 'n vader, die duiwel, wat die beliggaming van die leuen is (Joh 8:44) en nie waarheid in hom het nie.
} 
Ondertone word wel gehoor as die duiwel in Judas invaar (Joh 13:27), maar word nie tot 'n groot konfliktema ontwikkel nie.

\section{LEGITIMASIE VAN DIE AKSIELYN VAN VILIFISERENDE GEWELD: DIE EKSKLUSIWITEIT VAN JESUS}

Die patroon van vilifikasie bevestig weer dat die probleem gaan oor (Joodse) mense wat God verloor het en weens Satan se invloed nie God se wil doen nie. Dit word duidelik uit hulle oordele oor en optrede teenoor Jesus as die gestuurde van God. Die essensie van die probleem is dat hulle nie in God glo soos Hy in en deur Jesus openbaar word nie (Joh 1:9-11; 5:44-46; 8:24; 10:36-39; 15:23-24; kyk bv Metzner 2000). Die opponente van Jesus is sonder God, soos blyk uit hulle haat en verwerping van Jesus, met die gevolg dat die toorn van God op hulle rus. ${ }^{13}$ Aan die ander kant is die bewerings dat Jesus die openbaarder is van God, die Vader, weer die legitimasie van die aksielyne van die dissipels van Jesus. Die kern van die konflik en wedersydse vilifikasie word dus op die slagveld van die Christologie uitgeveg.

Die kern van die probleem is duidelik. Dit gaan nie oor kultiese praktyke, religieuse verlede, die bestaan van God, die aard van etiese eise of dergelike sake nie, maar oor die eksklusiwiteit van Jesus as Messias. Soos bo geargumenteer is, het die Johannese groep vanuit die Joodse religieuse omgewing beweeg met die eksklusiewe verkondiging dat die teenwoordigheid van God alleen in Jesus gevind kan word (Kok 2008:322; Van der Watt 2005). Die Jodedom wat dit nie wou aanvaar nie, was dus sonder God.

In Johannes 17:20-21 skets Jesus die nuwe (of ware) simboliese universum van die nuwe familie van God teenoor die Judese simboliese wêreld, deur gebruik te maak van 'n konsentriese argument (Haenchen 1980:506-508). Kok (2008:322) argumenteer God is in die sentrum, soos met die Joodse simboliese wêreld, maar nou gevolg deur Jesus en dan gelowiges (Kyk ook Joh 15:4). Die nuwe konsentriese simboliese heelal verskil van die Joodse een in die sin dat Jesus intiem verwant is aan die sentrum (God) en dat die progressiewe grade van heiligheid vervang word deur'n driedimensionele paradigma van eenheid. Hierdie eenheid is fundamenteel gevestig binne die konteks van liefde (Joh 20:26), nóú verbind of gekoppel aan openbaring (Joh 1:18). Daar kan ook geargumenteer word dat die eenheid binne die familie van God in die konteks van liefde geopenbaar word (Joh 15:9; contra 5:42). Elders (Joh 13:34; vgl ook 13:1-17) gebruik Jesus

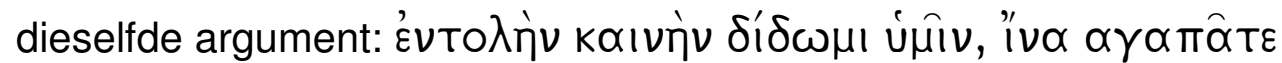

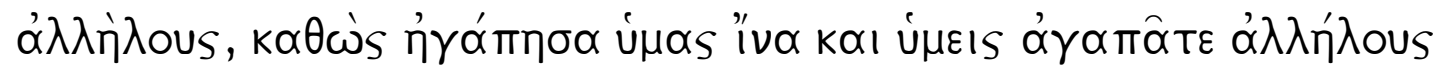

\footnotetext{
${ }^{13}$ Johannes 3:36; 5:24, Die begrip ópүr̀ kom net hier in Johannes se Evangelie en sy briewe voor).
} 
(Joh 13:34). In Johannes word die simboliese universum van die Jode geskets teen die agtergrond van die skepping van 'n nuwe geloofsgemeenskap of familie (vgl Joh 1:12). Jesus is die nuwe sentrum waar God teenwoordig is, wat by implikasie behels dat waar Jesus ookal is, God self is, en daar sal liefde en eenheid gevind word binne die matriks van die familie wat Jesus geskep het (Barrett 1978:216; Carson 1991:205; Morris 1995:203204; Schnackenburg 1990:1.399; Haenchen 1980:224-225).

Twee vrae verdien hier aandag: Hoe wesentlik is die eksklusiwiteit van Jesus vir religieuse outentisiteit? En hoe is die liefde met die geweldsoptrede (vilifikasie) deur Jesus se dissipels te versoen?

\subsection{Die eksklusiwiteit van Jesus}

Hoe wesentlik is die eksklusiwiteit van Jesus vir religieuse egtheid? Sou daar 'n Christologiese kompromie tussen die twee groepe opponente moontlik wees wat die geweld sou kon temper? Daar blyk binne die Johannese verhaal geen plek te wees vir kompromie, of versagting rondom die basiese belydenis van die eksklusiwiteit van Jesus nie. Juis daarom word die Christologie van hierdie Evangelie so doelgerig aangebied (Joh 20:30-31; Ridderbos 1997:650; Carson 1991:660-661). Dit is 'n kwessie óf van aanvaarding van Jesus om so deel van God se familie te word, óf verwerping van Jesus wat op die oordeel van God uitloop. Die outeur van Johannes funksioneer binne hierdie kontras. Grys gebiede bestaan nie op hierdie punt nie.

Tipies van die argumente van daardie tyd word hierdie stryd binne 'n transendente raamwerk geïnterpreteer. Die sogenaamde universele goddelike narratief vorm die teologiese basis vir al die verhale en seggings in die Evangelie (kyk Kok 2008). In die optrede en woorde van mense (en Jesus) word die groter, multidimensionele geestelike verhaal/drama ook duidelik. Dit kan ook vergelyk word met die moderne film "The Matrix" waarvolgens die aardse gebeure nie al is waaroor dit gaan nie. Volgens die film staan die aardse gebeure in direkte verband met en is dit 'n resultaat van die dinamiese multidimensionele realiteit wat agter die skerms afspeel. Agter die verhaal van die Evangelie staan die dinamiese verhaal van die kosmologiese konflik tussen die prins van hierdie wêreld en die liefdevolle Vader en sy gestuurde Seun (vgl Reinhartz 2001).

Dit is nie 'n stryd tussen mense nie, maar beide God en die duiwel is

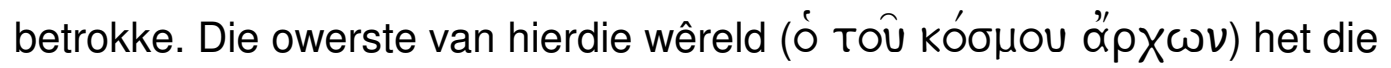
Seun van die Vader die stryd aangesê (Joh 12:31; 14:30; 16:11). Dit gaan dus om 'n veel groter stryd tussen God en die duiwel. Binne hierdie stryd is Jesus die gestuurde verteenwoordiger van God (Reinhartz 1992, 2001). 
Die vraag is nou: hoe wesentlik is hierdie eksklusiwiteit vir die etiese rigtinggewing van Johannes? Met ander woorde, wil Johannes hier sê dat daar op hierdie punt geen kompromie meer is nie en as hierdie grens oorskry word, verander die wesentlike aard van die Johannese groep? Binne die Johannese narratief vind ons geen getuienis dat daar op hierdie Christologiese punt toegegee of selfs 'n kompromie aangegaan kan word nie: nie om dit as die enigste waarheid te ontken; of om dit as een van baie waarhede te sien (Joh 10:7-10); of om die oordeel van God uit te skakel indien dit nie aanvaar word nie (Joh 3:36).

Dit wil dus voorkom of die Johannese groep sou voel dat hulle hulle identiteit sou prysgee indien die Christologiese belydenis en eksklusiwiteit daarvan ontken of selfs verander sou word. Dit word in die Johannesbriewe onomwonde bevestig ( 1 Joh 2; 2 en 3 Joh). Daar moet dus gekonkludeer word dat as daar rondom die Christusbelydenis en die uniekheid daarvan kompromieë gemaak word, die Johannese groep duidelik sou reageer deur te sê die persoon wat dit doen nie meer "van hulle" is nie (1 Joh 2).

Hermeneutiese oorweginge opper die verdere vraag: hoe situasiegebonde is die oordeel van die Johannesgroep? Sou daar'n situasie kon wees waarin hulle die eksklusiwiteit van Jesus sou prysgee? Die antwoord blyk nee te wees. In die eerste plek sien die Johannese groep hulself as deel van die Joodse geskiedenis wat met die skepping begin (Joh 1:3) en Moses, Abraham, Jesaja, die profete, engele en ander insluit. Hulle verbind hulself ook aan die lewende God van daardie geskiedenis. Dit is die God wat in die tempel van Jerusalem aanbid word (Joh 2:13; 4:20; vgl Köstenberger 2004:47; Lindars 1972:98; Keener 2003:422). By verstek speel ander gode nie 'n rol nie. Daar is maar een ware God wat in gees en waarheid aanbid word en dit is die God van die Jode (Joh 4:22). Binne hierdie spesifieke raamwerk van die enigste ware God word dan gevra waar, binne hierdie Joodse raamwerk waar God aanwesig moet wees, word God werklik aanbid met die veronderstelling dat God nie buite die raamwerk gevind en aanbid word nie. Die duiwel is immers die prins van die wêreld buite hierdie raamwerk. As dit dan waar is dat Jesus die enigste plek is waar God regtig aanbid kan word binne die (enigste) raamwerk waar die lewende God aanbid kan word, hoef die verdere implikasie nie eers bespreek te word nie. In ander godsdienste is God gewoon nie aanwesig nie en daarom hoef hulle eenvoudig nie in ag geneem te word nie. Daar kan dus nie 'n situasie voorgestel word waar Jesus sy unieke posisie as die Seun wat die Vader openbaar (Joh 1:18), kan afstaan, of waar daar 'n afgewaterde kompromie aangegaan kan word nie. As jy binne die historiese lyn van die Johannese groep (wil) staan, moet jy erken daar is iets soos goddelike waarheid. Jesus is daardie weg, die lig, die 
waarheid en die lewe (Joh 14:6); Hy is die enigste deur na saligheid vir die skape (Joh 10:7-10) en wie Hom nie het nie, het ook nie die Vader nie (Joh 14:10-11). Dit is ' $n$ vraag of ' $n$ mens jouself binne die historiese lyn van die Johannesgroep wil plaas, of jy sy oordeel as gesagvol wil aanvaar, en of jy dieselfde oortuigings op dieselfde absolute manier wil handhaaf, maar dit is vrae van 'n ander aard binne die raamwerk van die kanonieke debat. Indien jy hierdie kanonieke uitsprake aanvaar, lyk dit problematies om die uniekheid of sentraliteit van Jesus te ontken.

\subsection{Liefde en geweld}

Maar wat sê dit van die liefde? Die hoof etiese opdrag in die Evangelie is liefde (Van der Watt 2006; Schnackenburg 1990:1.399; Haenchen 1980:224225), hoewel die liefdesopdrag op die Johannese groep gemik is en dit as hulle kenmerk gesien moet word (Joh 13:34-35; Barrett 1978:216; Carson 1991:205; Morris 1995:203-204). Hoe is dit te rym met veral die vilifikasie van die kant van die dissipels van Jesus teenoor hulle opponente? Die vraag moet in die lig van die missionêre opdrag van die dissipels van Jesus beoordeel word. Die hooftaak van die volgelinge van Jesus na sy vertrek is hulle voortsetting van die missie van Jesus (Joh 17:18; 20:21), wat beteken dat hulle Jesus moet verkondig sodat mense die ewige lewe kan kry (Joh 20:31). Soos die Vader die wêreld liefgehad het, moet hulle as sy kinders ook die wêreld liefhê (Joh 3:16). Die liefde teenoor mense buite die Johannese groep vind dus sy spitspunt in die missie van Jesus en uiteindelik van sy volgelinge (Schnelle 1998:304-305).

Dit is ook opmerklik dat die retoriek teenoor die nie-Joodse groepe meer getemper is. Die vilifikasie ontbreek. Die Samaritane in hoofstuk 4 word beskryf as wit lande wat geoes moes word en hulle ontmoet en aanvaar dan ook die Redder van hierdie wêreld (Joh 4:41-42). Die Grieke word met die boodskap van Jesus wat mense na Hom toe trek gekonfronteer (Joh 12:20 vv). Uit uitsprake van skape wat elders in krale is (Joh 10:16, kyk ook 11:52; 17:20), kan afgelei word dat die sending buite die Joods-Palestynse raamwerk suksesvol was. Van al hierdie groepe word daar 'n positiewe beeld vanuit die oogpunt van Jesus en sy volgelinge geskets. Konflik is nie hier ter sprake nie anders as wat van die opponente van Jesus waar is. Op hierdie wyse deurbreek Jesus die geweldstaal en geweldshouding teenoor die Samaritane. Deur voorts siekes wat van geboorte af blind was (Joh 9) of agt-en-dertig jaar sonder hulp siek gelê het, te genees, deurbreek Jesus ook die geweldsiklus teen hulle. Hier kan wel van 'n geweldsiklus gepraat word omdat siekte destyds met die bose in verband gebring is. Jesus deurbreek verder die negatiewe houding teenoor die Romeine deur Pilatus implisiet onskuldig te 
verklaar toe hy verklaar het dat iemand anders groter skuld aan alles het as Pilatus (Joh 19:11).

Daar bestaan geen twyfel dat die vilifikasie deur die volgelinge van Jesus skerp en doelgerig was nie. Tog word dit getemper deur die liefde in die heilbrengende missie van Jesus en sy volgelinge. Die primêre opdrag is om Jesus as Messias te verkondig sodat die wat glo ewige lewe by God kan verwerf. In reaksie teenoor mense wat die missie gewelddadig teenstaan, word daar in strydgesprek gegaan met die wapens tot beskikking, naamlik, retoriese vilifikasie. Die vilifikasie deur die volgelinge van Jesus wil die verkeerde pad waarop die opponente hulle bevind, uitwys. Hulle is sonder God en tree dus verkeerd op, wat net 'n bewys is van hulle verbondenheid met die duiwel (kyk hierbo). In 'n sekere sin dien die vilifikasie dus ook as missionêre middel om die opponente van hulle blindheid te probeer genees ${ }^{14}$ (vgl Joh 9:40-41; 12:40; kyk die verband met Jes 6:10; vgl Kok 2008).

Twee argumente spreek ten gunste van 'n "missionêre vilifikasie". Die eerste is dat die Jode as sodanig nie negatief beskryf word nie behalwe as dit by die aanvaarding van en optrede teenoor Jesus kom. Die beeld van die algemene optrede van die Jode, met enkele uitsonderings, is positief. Daar word nie ontken dat die Jode, ook die dissipels van Moses se identiteit teruggaan na God se volk wat deur die woestyn getrek het en manna van God af ontvang het nie (Joh 6:31). Hulle is die mense wat die wet van Moses het (Joh 1:17; 5:45; 9:28-29), kan spog dat Abraham hulle voorvader was (Joh 8:33, 37, 39-40) en dat hulle met reg kinders van God genoem kan word (Joh 8:41). Hulle word verder as godsdienstig en toegewyd geteken. Hulle onderhou ywerig hulle kultus in die tempel (Joh 2:14-16) waar hulle leiers dit skynbaar goed organiseer (Joh 1:19; 7:32, 45; 11:46-47, 57; 12:10; 18:3, 35; 19:21). Dit is immers waar God aanbid moet word (Joh 2:13; 4:20; 5:1; 10:22; 11:55). Daarbenewens was hul sinagoges belangrike sentra vir sosioreligieuse aktiwiteite (Joh 9:22, 34-35; 12:42; 16:2). Verder word daar gesê dat hulle ywerige studente van die Skrif is wat hulle as die hoeksteen van hulle godsdienstige aktiwiteite sien. Hulle vind daarin die riglyne vir hulle verhouding met God (ewige lewe - Joh 5:39) en neem die voorspellings in die Skrif ernstig op (Joh 1:20-21, 45; 7:26, 40-44). Gemeet aan hulle begeerte om God te eer en te dien (Joh 9:24), wat selfs aan fanatiese ywer kon grens (Joh 16:2), het daar ook nie veel met hulle toewyding geskeel nie. Hulle was

\footnotetext{
${ }^{14}$ Kyk Kok (2008) vir 'n bespreking van "geestelike" genesing/restourasie in Johannes en die verband met bekering. Johannes neem Ou Testamentiese gedagtes rondom hierdie saak in teksgedeeltes soos Joh 9:40-41 en 12:40-41 oor (vgl Joh 12:40 se eksplisiete aanwending van Jes 6:10). Genesing/restourasie in Johannes moet ook die kategorie van geestelike genesing insluit. Bekering is reeds in die Ou Testament met die begrip genesing of restourasie in verband gebring ( $\mathrm{vgl}$ Jes 6:10). Ongelowigheid of ongehoorsaamheid word met die kategorie van siekte of gebrokenheid verbind (vgl o a 2 Kron 7:14).
} 
ernstig oor hulle reinheidswette (Joh $2: 6 ; 11: 55 ; 18: 28 ; 19: 42$ ) en het hulle religieuse feeste gehou (Joh 2:13; 5:1; 7:2, 10; 11:55; 12:1, 20; Ashton 1994:39-42), veral die Sabbat. Juis omdat hulle geoordeel het dat Jesus die Sabbat breek, wou hulle Hom doodmaak (Joh 5:16, 18; 7:22-23; 9:16). Hulle word dus as 'n groep geskets wat ernstig is oor hulle godsdiens en oor God. Die enigste probleem het by Christologiese kwessies opgeduik.

Daar is geen duidelike tekens van 'n onderliggende haat van Jesus se dissipels waardeur hulle alle positiewe eienskappe van die opponente ontken het nie. Inteendeel, die Jode word in hulle eie reg erken en in baie opsigte op 'n positiewe wyse geteken (Van der Watt 2005:105-107). Hierdie positiewe beeld van die Jode temper dus die vilifikasie deur die volgelinge van Jesus. Hierdie waardering van die Jode beteken dus dat die dissipels van Jesus nie vir hulle wou vernietig deur die vilifikasie nie. Die dissipels van Jesus fokus op 'n spesifieke probleem en verval nie in 'n algemene aanval nie. Dit moet ons dus lei na 'n sagter en meer funksionele interpretasie van die vilifikasie deur die volgelinge van Jesus. Hulle wou nie vernietig nie, maar binne hulle liefdevolle missie eerder red (Schnackenburg 1990:2.299; Carson 1991:388; Brown 1966:399). Die Johannese groep is dus so oortuig van die waarheid van hulle boodskap dat hulle reaksie op die geweldsaksies van die opponente met missionêre liefdesaksies beantwoord word. Soos Burridge (2007) ook redeneer, maak dit nie van die Johannese groep 'n klein sektariese binnegroep nie. Hulle is wel afgeskei van die groter Joodse opponente, maar stel hulle selfs vir die vyande van die Jode oop. Hulle vilifiserende taal is meer gemik op die redding van die opponente. Hulle vilifikasie word dus nie deur haat getipeer nie en loop ook nie op moord uit nie. Die vilifikasie van die opponente loop op dood uit en is gegrond in haat. Dit is op geen punt in die Evangelie van die volgelinge van Jesus waar nie. Hulle moor nie en daar word ook nie gesê dat hulle haat nie. Dit is die wesenlike verskil tussen die vilifikasie van die opponente en die dissipels van Jesus.

\section{HERINTERPRETASIE VAN DIE GEBEURE}

Een van die vernaamste wyses waarop geweld deur die opponente van Jesus in die Evangelie hanteer word, is via herinterpretasie van kontensieuse sake. Die herinterpretasie dien verskillende oogmerke, naamlik, om onder andere identiteit te skep teenoor groepe wat op 'n spesifieke wyse getipeer word en om die optrede van die gelowiges te vorm. ${ }^{15}$ Vir ons doeleindes kan ons hier

\footnotetext{
${ }^{15}$ Petersen (1993); Malina en Rohrbaugh (1998) maak baie van die groepstaal van die Johannese groep.
} 
onderskei tussen die dissipels van Jesus se rasionaliserende herinterpretasie van hul opponente en van hulle eie situasie.

Die matriks waardeur die outeur die situasie van die dissipels van Jesus beoordeel is dualisties (kontrasterend) van aard. Jesus kom van "bo" (Joh 3:31) en sy koninkryk is van daar (Joh 18:36). Dit staan teenoor hierdie wêreld (die "onder"). Sy volgelinge kry die ewige lewe en word kinders van God (Joh 1:12), wat beteken dat hulle aan 'n alternatiewe werklikheid (die "bo") behoort, wat onsigbaar en transendent is (Joh 3:3-6). Hoewel hulle nog op aarde leef, leef hulle daar as kinders van God. Laasgenoemde realiteit as kinders van God is egter dominerend ten opsigte van hulle lewensoriëntasie (Van der Watt 2000). Hulle leef nou as die familie van God. Hierdie "alternatiewe geestelike werklikheid" bied die moontlikheid en raamwerk vir effektiewe herinterpretasie, aangesien die identiteit en lewensin van die volgelinge van Jesus na hierdie geestelike werklikheid verplaas word. Daardeur beïnvloed hul aardse identiteit hulle lewenskeuses. Hulle lewensoriëntasie put uit hulle geestelike identiteit, hoewel hulle nog hier op aarde leef en bestaan. Die twee eksistensiële realiteite (die aardse en die transendente) koëksisteer met die dominante hemelse realiteit. Daarmee word hulle dan ook in 'n groot mate ontkoppel van wat in hierdie wêreld gebeur. Hulle beweeg dus nie alleen in 'n alternatiewe bestaanswyse in nie, maar 'n nuwe era van genade breek ook aan (Joh 1:17). So word die effek en invloed van die geweld wat die volgelinge van Jesus aangedoen word, getemper, aangesien dit nie wesenlike invloed op die hemelse realiteit uitoefen nie. Dit impliseer nie asketisme nie, want die dissipels moet nog missionêr hulle deel in hierdie wêreld doen. Enkele voorbeelde van die herinterpretasie kan as illustrasie dien.

\subsection{Herinterpretasie van die dood}

Hierdie is natuurlik een van die mees bespreekte en wydste temas in die Evangelie. Hier sal net enkele punte genoem word ter illustrasie.

Hoewel Jesus fisies doodgemaak word, leef hy voort selfs as sy aardse lewe van hom weggeneem word. Die passiewe gebruik in Johannes 2:22 (vgl $\eta\rceil \gamma \varepsilon \rho \theta \eta)$ dui in die Johannese konteks daarop dat die lewe en opstanding in die eerste plek sy oorsprong in God as bron van lewe het. Hier word die mag wat aan Jesus oorgedra word en waaroor Hy beskik, ook ten opsigte van sy beheer oor lewe en dood (Joh 10:17-18) sterk beklemtoon. Hy het die vermoë om sy aardse lewe weer terug te neem juis omdat Hy die ewige lewe het (Joh 10:17-18; 11:25-26). Immers, die Vader en sy Seun is in beheer van alles: byvoorbeeld, as Pilatus, die aardse heerser van die gebied, nie mag van bo ontvang nie, kan hy niks doen nie (Joh 18:11), want dit is Jesus wat lewe gee 
en neem (Joh 10:17-18). Vanuit die realiteit van God se plan word die werklikheid gestuur. Dit is dus belangrik om hier raak te sien dat Jesus, deur sy eie lewe op te gee, eintlik aan homself geweld pleeg of laat pleeg (Barrett 1978:377; Brown 1966:399). Dit doen hy binne die plan van God (Joh 10:17$18 ; 12: 27-33$ ) ten einde sy mag oor lewe en dood te illustreer en te bevestig dat hy die opstanding en die lewe is (Joh 11:24-25; Ridderbos 1997:362-365, Van der Watt 2003:127 e v). ${ }^{16}$

Die dood hou ook voordele in, soos duidelik is uit die beeld van die saad wat moet sterf om baie vrug op te lewer (Joh 12:24). Uit die gewelddadige optrede van die Jode kom daar dus voordeel vir die volgelinge van Jesus.

Die dood bied ook die geleentheid vir Jesus om sy mag en heerlikheid te illustreer, daarom word daar na die kruisgebeure verwys as die verheerliking van Jesus (Joh 7:39; 12:16; 17:1).

Op sodanige wyses word die oënskynlike geweldsaksie deur die opponente binne die absolute magsveld van Jesus geherinterpreteer. Dit ontneem egter nie die opponente van hulle skuld nie. Moord bly moord wat na die voorbeeld van hulle vader, die duiwel, geleef word en veroordeel sal word.

\subsection{Herinterpretasie van die geskiedenis}

In die vilifiserende gesprek in Johannes 8 gaan dit veral oor ware kindskap van God. Argumente oor die vryheid van die Jode en die kindskap van Abraham en selfs van God word gebruik, maar word telkens in terme van Jesus en die aanvaarding van sy sending geïnterpreteer. Hoewel die Jode fisieke afstammelinge van Abraham is, is hulle dit op die geestelike vlak nie meer nie (Joh 8:37 in die lig van 8:39). Hulle het dit prysgegee op daardie oomblik toe hulle versuim het om in Jesus te glo. In alle geval transendeer Jesus vir Abraham (Joh 8:58). Moses en Jesaja se getuienis en profesie word teen die opponente ten gunste van Jesus gedui (Joh $5: 45 ; 12: 38-41$ ). Die skrifte en profete getuig juis van Jesus (Joh 12:14; 19:37).

Die opponente het verder ook die fisieke tekens van God se pad met hulle deur die geskiedenis, die tempel, die skrifte en die kultus gehad. In die strydgesprekke tussen Jesus en sy opponente word die geskiedenis so geherinterpreteer dat die funksionele aspekte van die "bewyse uit die geskiedenis" in die persoon van Jesus konkretiseer. Op die wyse word die angel uit die vilifiserende taal van die opponente gehaal en die volgelinge van Jesus geregverdig. Gevolglik kan Jesus se volgelinge die geweldsoptrede uit

\footnotetext{
${ }^{16}$ Daar kan in die verband gevra word of Jesus se prysgawe van sy eie lewe dan nie selfmoord is nie (Joh 8:22). 'n Verdere probleem raak die skuld van byvoorbeeld Judas. Het hy werklik skuld aan die geweldsoptrede as hy maar net 'n rat in die groter plan van God was? Hierdie probleme word net genoem en gaan nie verder hier bespreek word nie.
} 
'n hoër morele posisie hanteer. Hulle word geweld aangedoen ter wille van die waarheid deur mense wat nie weet wat hulle doen nie. Die opponente is inderdaad blind (Joh 9:40-41). Hulle, as die dissipels van Jesus, wat kan "sien", verstaan hulle werklikheid vanuit die breër perspektief van die transendente werklikheid waaraan hulle deel gekry het deur geboorte van bo en die ewige lewe.

\subsection{Herinterpretasie van rolle}

Uit dit wat in die vorige punt genoem is, vloei die herinterpretasie van rolle voort. Die Fariseërs, hoëpriester, lede van die Joodse raad en ander was die fisieke geestelike leiers van die Joodse gemeenskap. Hulle kon mense uit die sinagoges gooi (Joh 9:34), hulle onderdane was bang vir hulle en hulle kon selfs die politieke leier, Pilatus, intimideer en manipuleer (Joh 19:12 vv). Die realiteit vanuit outeursperspektief is egter dat hulle moreel en teologies blind en in die duisternis is (Joh 9:40-41). Hulle oordele is verkeerd (Joh 7:24; 8:15) omdat hulle God nie ken nie (Joh 8:19). Hulle uiteindelike teregstelling van Jesus wat in die gees van leuens en moord plaasvind, plaas hulle in die magsveld van die duiwel (Joh 8:44). Hulle transendente verbondenheid word dus ook geherinterpreteer. Hulle is nie kinders van God nie, maar van die duiwel. Vanuit die werklikheid van wat Jesus gedoen het en wie sy volgelinge nou is, word die gewelddadige optrede van die opponente geherinterpreteer.

\subsection{Herinterpretasie van hulle eie identiteit}

Die volgelinge van Jesus het die ewige lewe en is die kinders van God. Hulle geniet die voorregte van die familie van God, die Koning. Daarvolgens kan hulle aanspraak maak op die beskerming van die Vader en die Seun (Joh $10: 28-30 ; 17: 11)$. Nie een van hulle sal verlore gaan nie en nie een sal geoordeel word nie. Hulle huidige status is die van vryheid van die sonde (Joh 8:32 vv). Hulle het die waarheid aan hulle kant, en word deur die Gees van God self binne die geweldskonteks van die bose gelei (Joh 16:7 vv) en beskerm (10:28-29).

Herinterpretasie van die werklikheid in die lig van die kontrasdenke van die Evangelie is dus ' $n$ kragtige meganisme om die aksielyne van geweld teen die volgelinge van Jesus te neutraliseer. Dinge word eenvoudig in 'n ander lig gesien. Die aardse het weinig impak op die hemelse, want wat aards is, is aards en wat hemels is, is hemels (vgl Joh 3:6; Barrett 1978:208; Carson 1991:190; Morris 1995:190). Hierdie werklikheidsperspektief skakel nie die geweldsoptrede uit nie, maar maak dit meer draaglik. Werklikheidsperspektief wat tot die herinterpretasie van essensiële identiteit lei, is dus 'n sleutelmeganisme in die neutralisering van geweld. 


\section{ENKELE KONKLUDERENDE OPMERKINGS}

Die Johannesevangelie, die Evangelie van liefde, is inderdaad ook 'n gewelddadige boek. Tog word die geweld op 'n geskakeerde, komplekse wyse aangebied wat vir hedendaagse Christene in 'n sekere sin rigtinggewend kan wees.

Binne die konflik tussen die dissipels van Moses en van Jesus gebruik beide groepe vilifikasie as geweldsmiddel, maar op verskillende wyses. In die geval van die opponente van Jesus gaan dit met haat saam wat op dood uitloop. Die oordeel daaroor is negatief en dit word beskryf as van die duiwel. In die geval van Jesus se dissipels gaan die vilifikasie met liefde saam wat moontlik op die lewe kan uitloop. Hieruit moet afgelei word dat vilifikasie met verskillende motiewe gepaard gaan en dat dit die etiese kwaliteit daarvan bepaal.

Die hermeneutiese vraag is: beteken dit dat die kerk van vilifikasie gebruik kan maak ten einde missionêr te kan werk? Met ander woorde, kan ander mense beskryf word as verkeerd, van die duiwel, blind en in die duisternis, ter wille daarvan om hulle tot die oortuiging van die waarheid van Jesus te bring? Die vraag is nie eenvoudig nie, veral nie as daar in gedagte gehou word dat in die antieke tyd strydgesprekke as "retoriese spel" gesien is waarvolgens die eer van 'n persoon en die waarheid van wat hy sê, getoets is nie. Vandag doen ons dit in ons situasie nie meer so nie en dit is veral in 'n postmodernistiese raamwerk glad nie aanvaarbaar nie, maar juis taboe. Enigiets wat in ons situasie na vilifikasie mag klink (selfs net degradering van ' $n$ ander of sy standpunt) word in die postmoderne tydgees bevraagteken.

Moet ons nou hieruit aflei dat vanweë postmoderne ingesteldhede die stel van 'n standpunt wat ander standpunte of mense in 'n sogenaamde negatiewe lig stel, taboe is? Hermeneuties moet 'n mens hier die teks tog ook ernstig neem. In hierdie teks word daar oor een enkele punt 'n streep getrek Die volgelinge van Jesus sou op baie punte kompromieë kon aangaan (Jesus as voorbeeld is baie positief oor die skrifte, profete, tempel, feeste, gebed ens), behalwe op die punt van die identiteit van Jesus as Seun van God wat uit die dood opgestaan het. Hy is die weg en die waarheid en die lewe wat mense na God toe lei. Vir daardie belydenis het die gelowiges die haat en geweld van die opponente verduur. Dit sou dus 'n anti-tekstuele lees vereis om te beweer dat die teks die indruk laat dat Jesus maar een van baie weë na God toe is of dat sy identiteit nie van belang is nie. Dit sien ons in die skerp reaksie in die Briewe toe daar aan die identiteit van Jesus getorring is.

Persone wat hulself dus binne die etos van die Johannese geskrifte stel en dit hermeneuties wil verwoord, sal ons insiens nie anders kan as om op die punt toe te gee dat die teks ' $n$ belydenis rondom ' $n$ vaste transendente waarheid 
vereis om geloofwaardig te funksioneer nie. Dit beteken dat die persoon wat met die Johannese teks erns wil maak, ten spyte van 'n relatiwistiese postmodernisme 'n waarheidsuitspraak rondom Jesus, in lyn met wat in die Evangelie gebied word, sal moet aanvaar.

Maar wat van die vilifiserende taal? De Beer (2007:8) beklemtoon dat taalgeweld, soos hy dit noem, wel tot fisieke moordende geweld kan lei, maar dat dit nie noodwendig so hoef te wees nie. In die Johannesevangelie kry ons die opponente van Jesus asook die dissipels wat beide vilifiserend optree. In die een geval lei dit tot moord en in die ander geval het dit die ewige lewe in die oog. Tog is die vilifisering wat in die teks die ewige lewe in die oog gehad het, jare later (valslik) gebruik as motivering vir geweld teen byvoorbeeld die Jode.

Die punt wat na vore gekom het, is dat die vilifikasie deur die volgelinge van Jesus daarop gemik was om positiewe gevolge vir die opponente te bewerk. Destyds was die manier om dit te doen binne die antieke retoriek en strydgesprekke. 'n Mens sou dus nie ongekwalifiseerd kan sê dat ons vandag ook die reg het om dit te doen nie, bloot omdat ons retories anders funksioneer. Ons meen tog dat 'n mens so ver kan gaan as om te sê dat retoriese middele tot ons beskikking, selfs al het dit 'n skerp kant rondom die stel van wat waar en vals is, gebruik kan word om 'n positiewe keuse vir Jesus, die Seun van God, uit te lok. Daartoe meen ons lei die teks ons.

Dit bring ons by die vraag van moorddadige geweld. Die opponente van Jesus het gemoor en dit was verkeerd, al het hulle gedink hulle doen God 'n guns (Joh 16:2). Selfs goedbedoelde geweld is verkeerd. Om te moor in die naam van God maak die moorddadige aksies nie reg nie.

Ons het egter ook gesien dat om ander mense dood te maak nie op die agenda van die volgelinge van Jesus was nie. Hulle vilifikasie het nie op enige wyse op sodanige geweld uitgeloop nie. Die rede was dat hulle vilifikasie ten doel gehad het om mense in Jesus te laat glo. Soos reeds vantevore gesê is, word die teks geweld aangedoen as daar op grond daarvan tot moord oorgegaan word soos latere Christengroepe wel met die Johannese teks as basis gedoen het. Die vilifikasie kan nie vernietiging van mense ten doel hê nie.

Dit bring ons weer by die vraag waarmee ons die eerste artikel begin het. Die situasie van die teks is ongebalanseerd deurdat die opponente van Jesus in die magsposisie is en daarom sonder probleme geweld tot op die vlak van moord kon beoefen. Die Christene kon nie op soortgelyke wyse reageer nie, want hulle was by verre in die minderheid. Gewapende reaksie sou hulle uitwissing beteken het. Gewapende teenstand was dus nie vir hulle 'n opsie nie. Die vraag is nou (om dit maar hipoteties te stel) of die destydse 
Christene hul opponente sou wou doodmaak as hulle die mag daartoe gehad het? Die teks gee geen rede om dit te vermoed nie. Die liefdevolle missie, waarvan die vilifikasie deel is, se oogmerk is, inteendeel, om mense by die lig van die wêreld, die Brood van die lewe uit te bring en nie om hulle lewens te neem nie. Daar is dus hermeneuties geen analogie wat 'n mens kan laat dink dat die neem van lewe 'n realistiese opsie vir die outeur sou kon wees nie. Geweld in Johannes, van die kant van die volgelinge van Jesus, word dus getemper en gekanaliseer deur die liefde van die Vader wat ook in sy kinders vir die wêreld tot uiting kom in die boodskap van Jesus Christus.

Vir ons geweldgeteisterdes in Suid-Afrika bied die Evangelie van Johannes ten minste die riglyn dat fisieke of moordende geweld nie die antwoord is nie en nooit die antwoord van die gelowige mag wees nie. Ons het 'n ander missie, naamlik om die waarheid van die Evangelie van Jesus, die Seun van God, as Redder van die wêreld te bly verkondig en hulle by die bron van ware lewe in oorvloed (10:10) uit te bring.

\section{Literatuurverwysings}

Ashton, J 1994. Studying John: Approaches to the Fourth Gospel. Oxford: Clarendon.

Bennema, C 2002. The power of saving Wisdom: An investigation of Spirit and Wisdom in relation to the soteriology of the Fourth Gospel. Mohr Siebeck: Tübingen.

Bieringer, R et al (ed) 2001. Anti-Judaism and the Fourth Gospel. Louisville, KY: Westminster John Knox.

Bietenhart, H 1986. s v Demon, air, cast out. NIDNT.

Barrett, C K 1978. The Gospel according to St John. $2^{\text {nd }}$ ed. Philadelphia, PA: Westminster.

Brown, R E 1966. The Gospel according to John, Vol 1, chapters 1-12. New York: Doubleday.

Bultmann, R 1955. Theology of the New Testament, 2 vols. New York: Scribner.

Burridge, R A \& Gould, G 2004. Jesus now and then. Grand Rapids, MI: Eerdmans.

Coloe, M L 2001. God dwells with us: Temple symbolism in the Fourth Gospel. Collegeville, MN: Liturgical Press.

De Beer, C S 2007 Filosofiese besinning oor geweld: Uitdagings aan informatiseringstrategieë. Tydskrif vir Geesteswetenskappe 47, 3-27.

De Boer, M C 2001. The depiction of "the Jews" in John's Gospel: Matters of behaviour and identity, in Bieringer, R D (ed), Anti-Judaism and the Fourth Gospel, 141-157. Louisville, KY: Westminster John Knox.

De Jonge, H J 2001. "The Jews" in the Gospel of John, in Bieringer, R D (ed), AntiJudaism and the Fourth Gospel, 121-140. Louisville, KY: Westminster John Knox.

Du Toit, A B 1994. Vilification as pragmatic device in early Christian epistolography, Biblica 75, 403-412. 
Esler, P F (ed) 1995. Modelling Early Christianity: Social scientific studies of the New Testament in its context. London: Routledge.

Golden, M 1990. Children and childhood in classical Athens. London: John Hopkins University Press.

Haenchen, E 1980. Johannesevangelium: Ein Kommentar. Tübingen: Mohr Siebeck.

Johnson, L T 1989. The New Testament's anti-Jewish slander and the conventions of ancient polemic. JBL 108, 419-441.

Kok, K 2008. Siekte en gebrokenheid teenoor genesing en restourasie in Johannes, $\mathrm{PhD}$ proefskrif, Universiteit van Pretoria.

Köstenberger, A J 2004. John. Grand Rapids, MI: Baker Academic.

Keener, C S 1993. The IVP Bible background commentary: New Testament. Downers Grove, IL: InterVarsity Press.

Keener, C S 2003. The Gospel of John, 2 vols. Peabody, MA: Hendrikson.

Lausberg, H 1960. Handbuch der literarischen Rhetorik. München: Hueber.

Lieu, J M 2001. Anti-Judaism and the Fourth Gospel: Explanation and hermeneutics, in Bieringer, R D (ed), Anti-Judaism and the Fourth Gospel, 101-120. Louisville, KY: Westminster John Knox.

Lindars, B 1972. The Gospel of John. London: Marshall, Morgan \& Scott.

Maier, G 1986. Johannesevangelium. Stuttgart: Hänssler. (Bibelkommentar Band 7.)

Malina, B J \& Rohrbaugh, R L 1998. Social-science commentary on the Gospel of John. Minneapolis, MN: Fortress.

Martyn, L 2003. History and theology in the Fourth Gospel, 3rd ed. Louisville, KY: Westminster John Knox.

Metzner, R 2000. Das Verständnis der Sünde im Johannesevangelium. Mohr Siebeck: Tübingen.

Mussner, F 1952. Die Anschaung vom "Leben" im Vierten Evangelium unter Berücksichtigung der Johannesbriefe. München: Karl Zink.

Neyrey, E 1995. Loss of wealth, loss of family and loss of honour: The cultural context of the original makarisms in Q, in Esler, P F (ed), Modelling early Christianity: Social scientific studies of the New Testament in its context, 139-158. London: Routledge.

Osiek, C \& Balch, D L 1997. Families in the New Testament world: Households and house churches. Louisville, KY: Westminster John Knox.

Petersen, N R 1993. The Gospel of John and the sociology of light. Valley Forge, PA: Trinity.

Reinhartz, A 2001. Befriending the beloved disciple: A Jewish reading of the Gospel of John. New York: Continuum.

Ridderbos, H 1997. The Gospel of John. Grand Rapids, MI: Eerdmans.

Roloff, J 1993. Die Kirche im Neuen Testament. Gottingen: Vandenhoeck

Schrage, W 1996. The ethics of the New Testament. Edinburgh: T\&T Clark.

Schattenmann, J 1986. s v Ecstacy, astonishment, distraction, horror, madness. NIDNT.

Stambauch, J \& Balch, D 1986. The social world of the first Christians. London: SPCK.

Van der Watt, J G \& Joubert, S J 1996. Hoe is Jesus gekruisig? HTS 52, 633-652.

Van der Watt, J G 2001. Fisiese en aardse families in die Evangelie volgens Johannes. Verbum et Ecclesia 22, 158-177.

Van der Watt, J G 2003. The cross/resurrection-events in the Gospel of John with special emphasis on the confession of Thomas (20:28). Neotest 37, 127-145. 
Van der Watt, J G 2005. Salvation in the Gospel according to John, in Van der Watt, J G (ed), Salvation in the New Testament, 101-131. Leiden: Brill.

Van der Watt, J G 2006. Ethics and ethos in the gospel according to John. ZNW 97, 147-176.

Van Tilborg, S 1993. Imaginative love in John. Leiden: Brill.

Wengst, K 2001. Das Johannesevangelium. 2 Teilband: Kapitel 11-21. Stuttgart: Kolhammer. (TKNT.) 